\title{
Stephanofilariasis in beef cattle - case report
}

\author{
[Estefanofilariose em bovinos de corte - relato de caso] \\ J. Schade ${ }^{1}$, M.S. Casa ${ }^{2}$, J.C. Lovatel ${ }^{3}$, M.C.S. Granella ${ }^{3}$, \\ T.G. Cristo ${ }^{2}$, R.A. Casagrande ${ }^{4}$, J.H. Fonteque ${ }^{4}$ \\ ${ }^{1}$ Universidade Positivo - Curitiba, PR \\ ${ }^{2}$ Programa de pós-graduação - Universidade do Estado de Santa Catarina - Lages, SC \\ ${ }^{3}$ Programa - de graduação - Universidade do Estado de Santa Catarina - Lages, SC \\ ${ }^{4}$ Universidade do Estado de Santa Catarina - Lages, SC
}

\begin{abstract}
Stephanofilariasis is an ulcerative dermatitis caused by nematodes that affect cattle in several countries in the world. However, it has not been described in beef cattle in Brazil. The objective of this study is to describe three cases of stephanofilariasis, which occurred in beef cows in the municipality of Ipê, RS, Brazil. The disease was characterized by pruritic, ulcerated and crusty seasonal lesions present in the cranial region of the udder. The diagnosis was confirmed by analyses of secretions stained smears and by direct optical microscopic examination of the sediment and the treatment was effectively carried out with topical trichlorphon. This report indicates that stephanofilariasis should be included as a differential diagnosis for dermatopathies in beef cattle in Brazil.
\end{abstract}

Keywords: dermatitis, nematode, Stephanofilaria spp, lactation ulcer

\section{RESUMO}

A estefanofilariose é uma dermatite ulcerativa causada por nematódeos que acometem bovinos em vários países do mundo, no entanto não tem sido descrita em bovinos de corte no Brasil. O objetivo do trabalho é a descrição de três casos de estefanofilariose em vacas de corte ocorridos no município de Ipê, RS. A enfermidade foi caracterizada por lesões sazonais pruriginosas, ulceradas e crostosas, presentes na região cranial do úbere. $O$ diagnóstico foi confirmado pela análise dos esfregaços corados das secreções e por exame direto do sedimento em microscopia óptica, e o tratamento foi realizado de maneira eficaz. com triclorfon tópico. Este relato demonstra que a estefanofilariose deve ser incluída como diagnóstico diferencial nas dermatopatias em bovinos de corte no Brasil.

Palavras-chave: dermatite, nematódeo, Stephanofilaria spp., úlcera de lactação

\section{INTRODUCTION}

Stephanofilariasis is a cutaneous disease caused by nematodes of Stephanofilaria spp. genus that affects several animal species worldwide (Miyakawa et al., 2010). In cattle, it is clinically characterized by chronic, ulcerated, crusty and itchy skin lesions, which are distributed throughout different regions of the body surface (Miyakawa et al., 2009). It also presents seasonal character, with greater occurrence in hot and rainy periods due to a larger proliferation of

Recebido em 5 de agosto de 2018

Aceito em 17 de abril de 2019

E-mail: schademv@gmail.com transmitter vectors. Those spreaders include Musca conduncens and Haematobia irritans (Miyakawa et al., 2010).

In beef cattle, this disease is economically relevant due to the stress associated with itchiness, responsible for reducing productivity (Pazinato et al., 2013), as well as strain and treatment-related expenditures (Miyakawa et al., 2012). In addition, the importance of this disorder lies in the disfigurement of the skin which may reduce the value of hides (Johnson et al., 1981; Novaes et al., 1988), contributing to restrictions to its commercialization. 
The disease is commonly reported in beef cattle (Johnson et al., 1986; Watrelot-Virieux and Pin, 2006). However, in Brazil, it has only been reported in dairy herds, affecting especially the cranial region of the mammary gland in lactating dairy cows (Miyakawa et al., 2009). Considering the absence of reports concerning the disease in beef cattle in Brazil, the objective of this study is to report three cases of stephanofilariasis dermatitis in beef cattle that occurred in a rural property in Ipê, RS, Brazil.

\section{CASUISTRY}

Clinical care was performed on a cattle herd at a farm located in the municipality of Ipê $\left(28^{\circ}\right.$ $49^{\prime} 12$ "S; 51 ${ }^{\circ} 16^{\prime} 45^{\prime \prime} \mathrm{W}$ ), in the state of Rio Grande do Sul, Brazil, due to the occurrence of pruritic cutaneous lesions in the cranial region of the udder. Three lactating cows, five to eight months in milk, presented the disease. The herd is comprised of 32 Red Angus cattle: 16 cows, 15 calves and 1 bull, raised in an extensive system over a 20 hectare area. There had been a history of similar cases in the three previous years, always occurring in the summer period between January and March, with clinical remission in the winter. In the previous year, the lesions were observed in two of the three affected animals. According to the owner, cattle infestation by flies is a problem in the farm, which most recently has been fought with diazinon impregnated ear tags. Parasitic control, including ticks and endoparasites, is performed with ivermectin and doramectin based products, the latter being administered 20 days prior to treatment. The farmer carried out an inconsistent topical application of a dichlorphention-based product, for whom he reported partial lesion regression.

After the assessment and clinical characterization of the lesions, materials for laboratory tests were collected. In order to carry out this procedure, the animals were sedated with a xylazine dose of 0.1 to $0.13 \mathrm{mg} / \mathrm{kg}$ applied intravenously and restrained in a lateral decubitus position using ropes. The collection of secretions was performed by superficial scaling of the lesion edge for subsequent smear stained with
Romanowsky type (rapid panoptic). Three fragments of tissue adjacent to the border of each wound were collected by means of a $6 \mathrm{~mm}$ punch biopsy. One fragment was prepared in formalin for histopathological examination and the other two were immersed in physiological solution $(\mathrm{NaCl} 0.9 \%)$ for direct examination of the pellet under optical microscopy (Miyakawa et al., 2009). Data related to the clinical characterization of lesions and histopathological findings will be described separately for each animal.

Animal 1: There were two circular ulcer lesions with raised borders cranial to the left front mammary quarter, with dimensions of $3.5 \mathrm{~cm} \mathrm{x}$ $3.0 \mathrm{~cm}$ and $2.5 \mathrm{~cm} \times 4.0 \mathrm{~cm} \quad\left(A=8.35 \mathrm{~cm}^{2}\right)$. Secretion with blood and hemorrhagic crusts (Figure 1A), associated with dipterous larvae (myiasis) were verified. Histopathological examination revealed an accentuated, multifocal infiltrate in the superficial and deep dermis, associated with proliferation of fibroblasts with a moderate amount of collagen and angiogenesis. The sample was comprised predominantly of eosinophilic infiltrate, as well as an infiltration of macrophages, lymphocytes and plasma cells. There was focal evidence of extensive necrosis with deposition of serocellular crusts on the epidermis.

Animal 2: Presented a circular ulcerated lesion cranial to the teat of the right front mammary quarter with dimensions of $2.5 \mathrm{~cm} \times 3.0 \mathrm{~cm}$ $\left(A=5.97 \mathrm{~cm}^{2}\right)$, small amount of blood secretions and hemorrhagic crusts on the wound periphery. There was another smaller lesion $(1.5 \mathrm{~cm} \mathrm{x}$ $1.0 \mathrm{~cm}, \mathrm{~A}=1.22 \mathrm{~cm}^{2}$ ) on the teat near the udder base with small amount of hemorrhagic crusts and multiple skin wounds (Figure 1B). Histopathological findings were characterized by a multifocal, accentuated infiltrate in the superficial and deep dermis, mainly around the blood vessels (Figure 2A). It consisted mainly of eosinophils infiltrate in addition to macrophages, lymphocytes and plasma cells. On the epidermis, there was focal evidence of extensive necrosis with deposition of serocellular crusts, acanthosis and moderate diffuse hyperkeratosis (Figure 2B). 


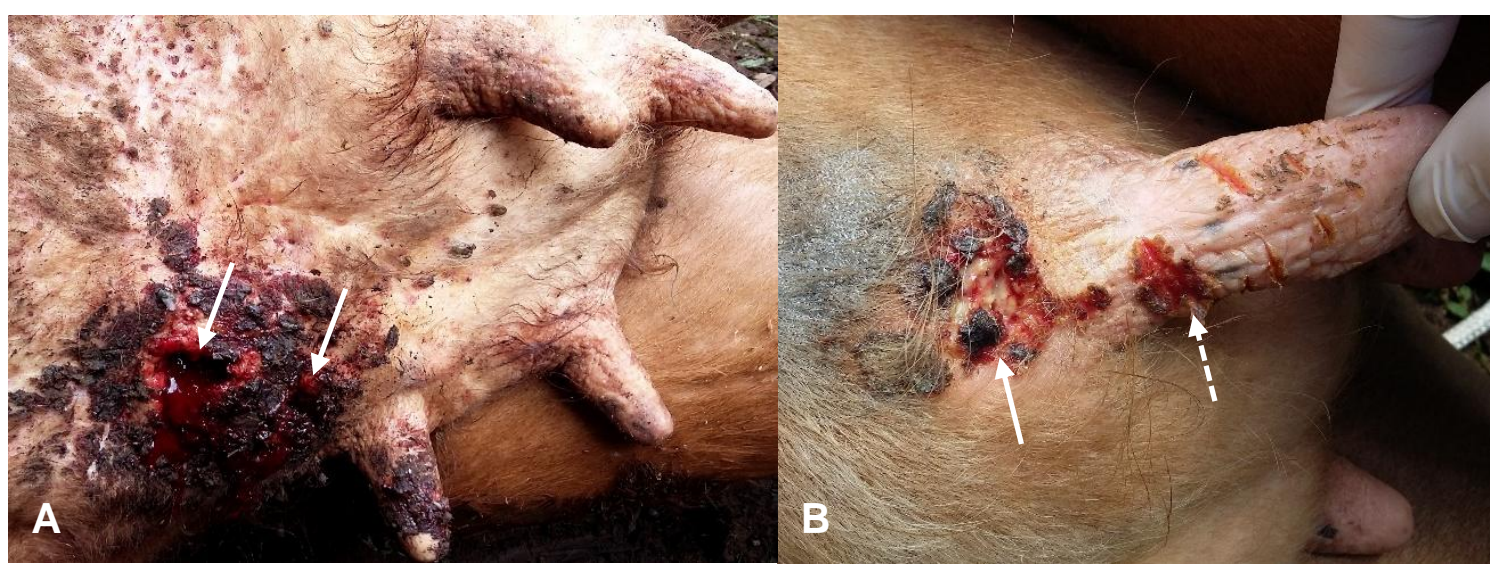

Figure 1. Stephanofilariasis in Red Anguls cows occurred in the municipality of Ipê-RS, Brazil. (A) Two ulcerated circular lesions cranial to the left front mammary quarter. Secretion with blood and hemorrhagic crusts cranial to the left front mammary quarter (arrows). (B) Ulcer lesion immediately cranial to the teat of the right mammary quarter, with small amount of blood and hemorrhagic crusts (arrow). Smaller lesion on the teat near the udder base, with small amounts of hemorrhagic crusts and multiple skin lesions (dashed arrow).

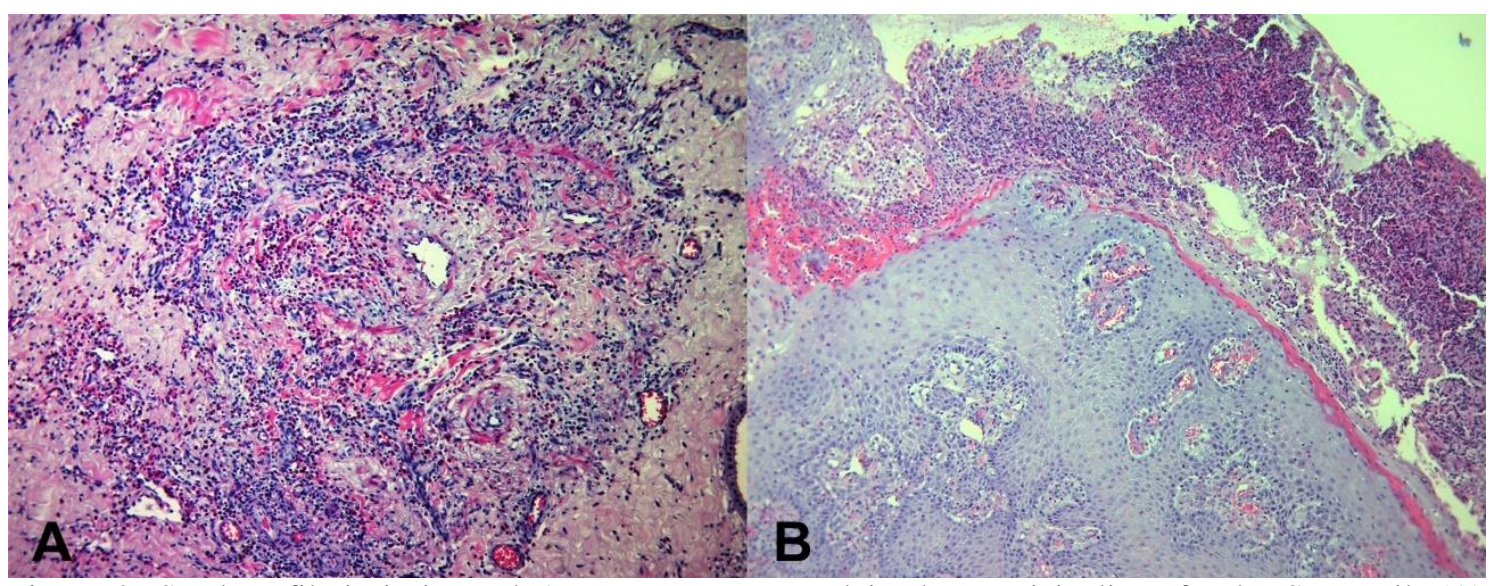

Figure 2. Stephanofilariasis in Red Angus cows occurred in the municipality of Ipê-RS, Brazil. (A) Dermis exhibiting focal infiltrate predominantly comprised of eosinophil, as well as macrophages, lymphocytes and plasma cells, accentuated mainly around the blood vessels (HE, 20x) (B). There was moderate diffuse acanthosis and serocellular crust deposition on the epidermis (HE, 20x).

Animal 3: The lesion appeared as a circular ulcer in the transition region between the udder skin and the abdomen, immediately right to the midline, with dimensions of $2.0 \mathrm{~cm} \times 3.0 \mathrm{~cm}$ $\left(A=7.07 \mathrm{~cm}^{2}\right)$. There was presence of serosanguineous exudate and hemorrhagic crusts. Histopathological findings revealed a multifocal, accentuated infiltrate on the superficial and deep dermis associated with proliferation of fibroblasts with a moderate amount of collagen and angiogenesis. It consisted mainly of eosinophilic infiltrate as well as infiltrate of macrophages, lymphocytes and plasma cells. The epidermis showed extensive focal necrosis with deposition of serocellular crusts. Microscopic analysis of stained smears (Figure 3A), as well as direct examination of the sediment (Figure 3B), evidenced the presence of Stephanofilaria spp. in samples taken from all affected animals.

The treatment consisted of wound cleaning, followed by topical application of Triclorfon paste at $6 \%$ twice a day until complete remission of the lesion (Miykawa et al., 2012), which, according to the farmer, occurred within seven days in all animals. 


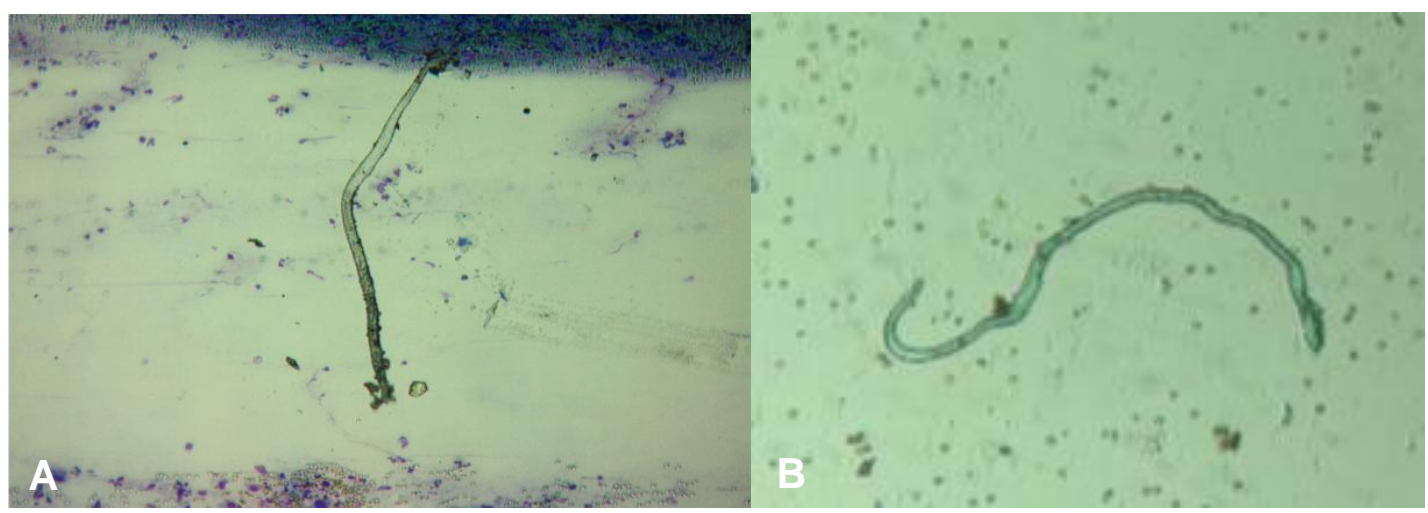

Figure 3. Images of Stephanofilaria spp. observed in the secretions' smears (A) and in the sediment direct examination (B), confirming the diagnosis of stephanofilariasis in Red Angus cows in the municipality of Ipê-RS, Brazil.

\section{DISCUSSION}

This report comprises the first description of stephanofilariasis in beef cattle in Brazil. Reports related to the disease in Brazil have shown exclusive occurrence in dairy breeds cattle (Novaes et al., 1988; Miyakawa et al., 2009; Silva et al., 2010; Pazinato et al., 2013). On the other hand, in other countries the disease has been reported especially in beef cattle. In beef cattle, it is possible to consider resistance to the disease in Bos indicus cattle when compared to Bos taurus cattle (Johnson et al., 1986, Dies and Pritchard, 1985, Johnson and Toleman, 1988). Therefore, studies in this field are necessary in order to establish the epidemiological characteristics of the disease in beef herds in Brazil.

In this study, lesions were observed in $9.4 \%$ (3/32) of the herd, similar to that found by Novaes et al. (1988), which showed lesions in $4.3 \%(5 / 115)$ of the animals in a dairy herd of the Holstein breed. In a study conducted by Miyakawa et al. (2009) in seven dairy herds in the municipalities of Santana do Itararé, PR and Itaberá, $\mathrm{SP}$, the disease was present ranging from $2.8 \%$ to $21.2 \%$ of the animals in the first year of evaluation. However, outbreaks of the disease can reach a substantial percentage of the herd, as demonstrated by Pazinato et al. (2013), when lesions struck $69.2 \%(9 / 13)$ of the animals in a dairy herd of the Holstein breed.

In summer periods, the occurrence of lesions is higher, in agreement with other authors, who reported the disease in dairy cows in Brazil. This fact is associated to the proliferation of the parasite biological transmitter vector in rainy seasons (Novaes et al., 1988; Miyakawa et al., 2009). Flies, including Musca conducens and Haematobia irritans, have been blamed as intermediate hosts and transmitters of Stephanofilaria spp. to cattle (Miyakawa et al., 2010). In fact, the infestation by flies was reported by the farmer and observed in the cattle herd at the time of evaluation; however, taxonomic identification was not carried out.

The distribution of lesions throughout the body surface appears to vary according to the geographic region and Stephanofilaria species. It has been described appearing in the ventral abdominal region, medial canthus of the eye (North America), around the eyes, neck, withers, dew claws, (Indonesia), scapular region, limbs (India and Russia), teats and muzzle (Japan) (Miyakawa et al., 2010). In Brazil, most reports describe lesions occurring on the cranial part of the udder in dairy cows, which is commonly known as "lactating ulcer" (Miyakawa et al., 2009; Pazinato et al., 2013). Theses lesions, usually called "lactating ulcers" have not been reported occurring in beef cattle in other countries. Therefore, the present study findings emphasize that the geographic region influences the distribution of lesions. It also suggests that it occurs independently of the affected breed propensity to the disease. Stephanofilaria species associated with lesions in cattle appear to vary according to geographic region and include $S$. dodesi (Indonesia), S. stilesi (USA and Russia), S. kaeli (Malaysia), S. assamensis (India and Russia) and S. okinawaensis (Japan) (Miyakawa 
et al., 2009). However, none of the few studies conducted in Brazil have identified the species involved (Miyakawa et al., 2010). Therefore, future studies related to classification of Stephanofilaria species existing in Brazil could elucidate which body part is most prone to be affected by lesions (Miyakawa et al., 2009).

The characteristics of the lesions were similar to those observed in lactating dairy cows at the same location. The wounds were circular, ulcerated, with hemorrhagic crusts and serosanguineous exudate (Miyakawa et al., 2009; Pazinato et al., 2013). The lesions dimensions were within the range found by Miyakawa et al. (2009), ranging from $0.78 \mathrm{~cm}^{2}$ to $44.16 \mathrm{~cm}^{2}$. This variation was attributed to the different stages in the evolution of cases. Novaes et al. (1988) observed lesions with the same characteristics in dairy cows in Brazil, but in other parts of the body, including the skin near the tail, back and thigh. Dipterous larvae (myiasis) may be present due to the flies' attraction to the lesions, findings which were also observed by Miyakawa et al. (2009) and Pazinato et al. (2013).

Stephanofilariasis diagnosis was initially based on the history and clinical characteristics of the lesions and was later confirmed by microscopic analysis of the secretions stained smears and by direct examination of the sediment, which allowed visualization of the parasite in all samples analyzed. Miyakawa et al. (2009), when comparing diagnostic methods to detect stephanofilariasis, observed the presence of adult parasite forms in $100 \%$ of the samples by direct examination of the sediment under a microscope. The authors considered the method effective and easy to be performed in order to confirm the diagnosis, which can be reaffirmed in the present report. The analysis of secretions stained smears can also be considered effective, since they exhibited the parasite in all the samples, corroborating other authors (Novaes et al., 1988; Pazinato et al., 2013). Histopathological examination, in turn, did not allow the observation of larval or adult forms of Stephanofilaria spp., Therefore, the findings only suggested the diagnosis, similar to that observed by Miyakawa et al. (2009) in dairy cows.
The treatment instituted by means of topical application of triclofon was considered effective, since it promoted remission of all lesions in a short period of time, similar to that observed by Pazinato et al. (2013). Miykawa et al. (2012) compared different treatment protocols for stephanofilariasis and concluded that the topical application of trichlorfon $6 \%$ was the most advantageous because it presented the best costbenefit ratio. In the present study, a rapid healing was observed, which can be attributed to the small size of lesions, given that there is a correlation between the wound area and treatment course (Novaes et al., 1988; Rai et al., 1994; Miykawa et al., 2012). Although parenteral use of ivermectin has been described for treatment, prior use of the product by the farmer has not resulted in lesion resolution, neither a regression. Similar finding was evidenced by Gill et al. (1991) in seven (7/17) bulls with lesions on the ear.

\section{CONCLUSION}

This is the first report of stephanofilariasis in beef cattle in Brazil, therefore clinical and epidemiological studies are necessary to characterize the disease and evaluate its possible economic impact in beef cattle in the country.

\section{REFERENCES}

DIES, K.H.; PRITCHARD, J. Bovine stephanofilarial dermatitis in Alberta. Can. Vet. J., v.26, p.361-362, 1985.

GILL, B.S.; BALAKRISHNAN, P.; LUMSDEN, G.G. et al. Treatment of stephanofilariosis ('earsore') with ivermectin. Vet. Parasitol., v.40, p.159-163, 1991.

JOHNSON, S.J.; ARTHUR, R.J.; SHEPHERD, R.K. The distribution and prevalence of stephanofilariasis in cattle in Queensland. Aust. Vet. J., v.63, p.121-124, 1986.

JOHNSON, S.J.; PARKER, R.J.; NORTON, J.H. et al. Stephanofilariasis in cattle. Aust. Vet. J., v.57, p.411-413, 1981 .

JOHNSON, S.J.; TOLEMAN, M.A. Prevalence of stephanofilariasis in young Bos indicus cattle in Northern Australia. Vet. Parasitol., v.29, p.333-339, 1988. 
MIYAKAWA, V.I.; REIS, A.C.F.; LISBÔA, J.A.N. Comparação entre protocolos de tratamento para a estefanofilariose em vacas leiteiras. Semin. Ciênc. Agrár., v.33, p.343-350, 2012.

MIYAKAWA, V.I.; REIS, A.C.F.; LISBÔA, J.A.N. Estefanofilariose em bovinos. Semin. Ciênc. Agrár., v.31, p.479-486, 2010.

MIYAKAWA, V.I.; REIS, A.C.F.; LOSBÔA, J.A.N. Aspectos epidemiológicos e clínicos da estefanofilariose em vacas leiteiras e comparação entre métodos de diagnóstico. Pesqui. Vet. Bras., v.29, p.887-893, 2009.

NOVAES, A.P.; COSTA, A.J.S.; BARBOSA, R.T. et al. Dermatite ulcerosa em bovinos provocada por Stephanofilaria. Pesqui. Agropecu. Bras., v.23, p.927-929, 1988.

PAZINATO, R.; KLAUCK, V.; LOPES, L.S. et al. Stephanofilariasis in dairy cattle: the need for early diagnosis and treatment. Vet. Zootec., v.20, p.582-587, 2013.
RAI, R.B.; AHLAWAT, S.P.S.; SINGH, S. et al. Levamisole hydrochloride: an effective treatment for stephanofilarial dermatitis (humpsore) in cattle. Trop. Anim. Health. Prod., v.26, p.175176, 1994.

SILVA, L.A.F.; RABELO, R.E.; MOURA, M.I. et al. Epidemiological aspects and treatment of parasitic lesions similar to Stephanofilariasis disease in nursing cows. Semin. Ciênc. Agrár., v.31, p.689-698, 2010.

WATRELOT-VIRIEUX, D.; PIN, D. Chronic eosinophilic dermatitis in the scrotal area associated with stephanofilariasis infestation of Charolais bull in France. J. Vet. Med., v.53, p.150-152. 